\title{
Geology
}

\section{Impact of Indus River discharge on productivity and preservation of organic carbon in the Arabian Sea over the twentieth century}

Andreas Lückge, Gaudenz Deplazes, Hartmut Schulz, Georg Scheeder, Axel Suckow, Sabine Kasten and Gerald H. Haug

Geology 2012;40;399-402

doi: $10.1130 / G 32608.1$

\section{Email alerting services}

\section{Subscribe}

\section{Permission request}

click www.gsapubs.org/cgi/alerts to receive free e-mail alerts when new articles cite this article

click www.gsapubs.org/subscriptions/ to subscribe to Geology

click http://www.geosociety.org/pubs/copyrt.htm\#gsa to contact GSA

Copyright not claimed on content prepared wholly by U.S. government employees within scope of their employment. Individual scientists are hereby granted permission, without fees or further requests to GSA, to use a single figure, a single table, and/or a brief paragraph of text in subsequent works and to make unlimited copies of items in GSA's journals for noncommercial use in classrooms to further education and science. This file may not be posted to any Web site, but authors may post the abstracts only of their articles on their own or their organization's Web site providing the posting includes a reference to the article's full citation. GSA provides this and other forums for the presentation of diverse opinions and positions by scientists worldwide, regardless of their race, citizenship, gender, religion, or political viewpoint. Opinions presented in this publication do not reflect official positions of the Society.

\section{Notes}

(C) 2012 Geological Society of America

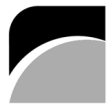

THE

GEOLOGICAL

SOCIETY

OF AMERICA 


\title{
Impact of Indus River discharge on productivity and preservation of organic carbon in the Arabian Sea over the twentieth century
}

\author{
Andreas Lückge', Gaudenz Deplazes², Hartmut Schulz³, Georg Scheeder ${ }^{1}$, Axel Suckow ${ }^{4}$, Sabine Kasten ${ }^{5}$, and \\ Gerald H. Haug ${ }^{2}$ \\ 'Bundesanstalt für Geowissenschaften und Rohstoffe (BGR), 30655 Hannover, Germany \\ ${ }^{2}$ Geological Institute, Department of Earth Sciences, ETH Zürich, 8092 Zürich, Switzerland \\ ${ }^{3}$ University of Tübingen, 72076 Tübingen, Germany \\ ${ }^{4}$ Institut für Angewandte Geophysik, 30655 Hannover, Germany \\ ${ }^{5}$ Alfred Wegener Institute for Polar and Marine Research, 27570 Bremerhaven, Germany
}

\begin{abstract}
Marine high-productivity zones along the continents are of great economic importance, and they account for most organic carbon burial. The carbon cycle in many coastal zones is influenced by the sediments and dissolved nutrients introduced by rivers. However, there is little direct evidence for a regional marine response to changes in river dynamics. Here we present a suite of high-resolution records of organic and inorganic paleoceanographic proxies, which together demonstrate that past changes in Indus River discharge have strongly affected productivity patterns in the coastal northeastern Arabian Sea. Anthropogenic activity, including the building of dams and irrigation facilities during the past century, has drastically decreased the discharge rate of the Indus River. Between A.D. 1890 and 1998, the period over which this reduction occurred, primary productivity off the Pakistan coast seems to have decreased by more than one-third. Over the same period, the regional oxygen minimum zone weakened, increasing the supply of oxygen to the sediments, leaving the expected imprint on a suite of redox-sensitive elements and reducing the preservation of organic matter.
\end{abstract}

\section{INTRODUCTION}

Primary productivity and sedimentation patterns in the northeastern Arabian Sea, one of the world's major high-productivity areas, are characterized by large seasonal contrasts due to reversing monsoons. During boreal summer, southwesterly monsoon winds induce strong upwelling and thus high productivity, particularly in the western Arabian Sea (Prell and Kutzbach, 1992). During boreal winter, northeasterly winds trigger convective turnover of water masses and stimulate a second productivity maximum throughout a single monsoon cycle in the eastern Arabian Sea (Haake et al., 1993; Reichart et al., 1998).

The monsoons also play a significant role in the global hydrological cycle and dominate the water discharge of large rivers in the tropical to subtropical latitudes (Kale, 2007; Kudrass et al., 2001). Suspended loads and nutrients through riverine input can have a significant impact on the biogeochemistry and thus the productivity in the marine realm (Syvitski et al., 2005). In the Arabian Sea, freshwater is mainly supplied by the Indus River (Pakistan). The Indus River is one of the largest contributors of sediment and water to the world oceans, and drains an area of $~ 950,000 \mathrm{~km}^{2}$ (Ittekkot and Arain, 1986). Nearly $90 \%$ of the water reaching the river mouth is supplied from glaciers located in the Himalaya and Karakoram mountain ranges. The total freshwater runoff is $\sim 100 \mathrm{~km}^{3} / \mathrm{yr}$ (Karim and Veizer, 2002), carrying $\sim 100 \times 10^{6} \mathrm{t} / \mathrm{yr}$ of sediments (Milliman et al., 1984). However, starting more than $100 \mathrm{yr}$ ago, and particularly over the past $70 \mathrm{yr}$, series of barrages and irrigation facilities, resulting from urbanization, have been built. As a consequence, water and sediment discharge were diminished drastically, by as much as 70\%-90\% (Ittekkot and Arain, 1986; Inam et al., 2007). This perturbation of the natural ecosystem makes it ideal to study the influence of varying freshwater and nutrient supply on oceanographic conditions like variations in primary productivity and subsequent burial of organic matter in the Arabian Sea (in the vicinity of the Indus River mouth). It also enables us to assess trends in Indus River discharge rates over the past centuries.

\section{STRATIGRAPHY AND SAMPLING}

We use a well-preserved sediment core (SO130-288MC) that was recovered at the flank of the Indus Canyon off the Indus mouth $\left(23^{\circ} 07.37 \mathrm{~N}, 66^{\circ} 29.83 \mathrm{E}\right.$; $569 \mathrm{~m}$ water depth; Fig. 1). The 54-cm-long undisturbed core was retrieved from the center of an oxygen minimum zone (OMZ). The sediments are in most parts dark colored and indistinctly laminated. The uppermost $5 \mathrm{~cm}$ consist of nearly nonlaminated, brownish sediments.

The age model is based on ${ }^{210} \mathrm{~Pb}$ dating of a neighboring core (SO130-285MC), which could be well correlated to SO130-288MC (Fig. DR3 in the GSA Data Repository $\left.{ }^{1}\right)$. The ${ }^{210} \mathrm{~Pb}$ activ-

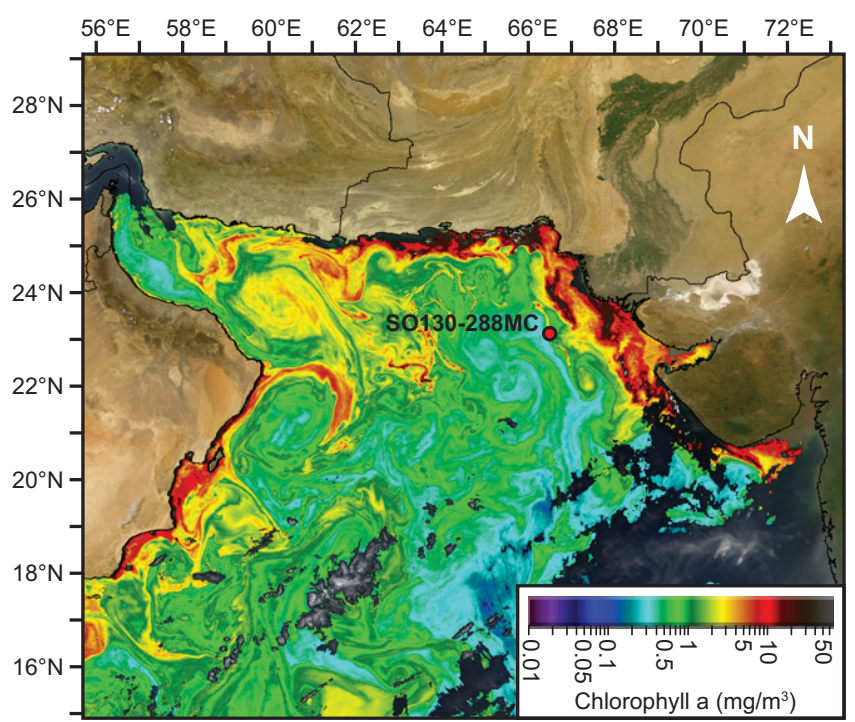

${ }^{1}$ GSA Data Repository item 2012123, details regarding the methodologies used and the results of age dating, sea-surface temperatures, TOC measurements (Figures DR1-DR3), and organic matter composition and grain sizes (Tables DR1-DR2), is available online at www.geosociety.org/pubs/ft2012.htm, or on request from editing@geosociety.org or Documents Secretary, GSA, P.O. Box 9140, Boulder, CO 80301, USA. 
ity (Fig. DR1) indicates a constant sedimentation rate of $0.7 \mathrm{~mm} / \mathrm{yr}$, in agreement with slope-wide sedimentation rates (Cowie et al., 1999). The ${ }^{210} \mathrm{~Pb}$ age model is reliable for the uppermost $12 \mathrm{~cm}$, equivalent to $170 \mathrm{yr}$. Beyond the ${ }^{210} \mathrm{~Pb}$ dating limit, we assume constant sedimentation rates for the entire core, thus spanning the past $650 \mathrm{yr}$ from A.D. 1998 to ca. 1350. (For a full description of methods, see the Data Repository.)

\section{Marine Sediment Proxies for Productivity and OMZ Decline}

We used clusters of organic and inorganic proxies to discriminate between early diagenetic and climate sensitive processes in the sediments (Fig. 2). Redox-sensitive elements (e.g., van der Weijden et al., 1999) show a characteristic depth succession of solid phase peaks. Mn and Fe are enriched in the uppermost part of the sedimen-

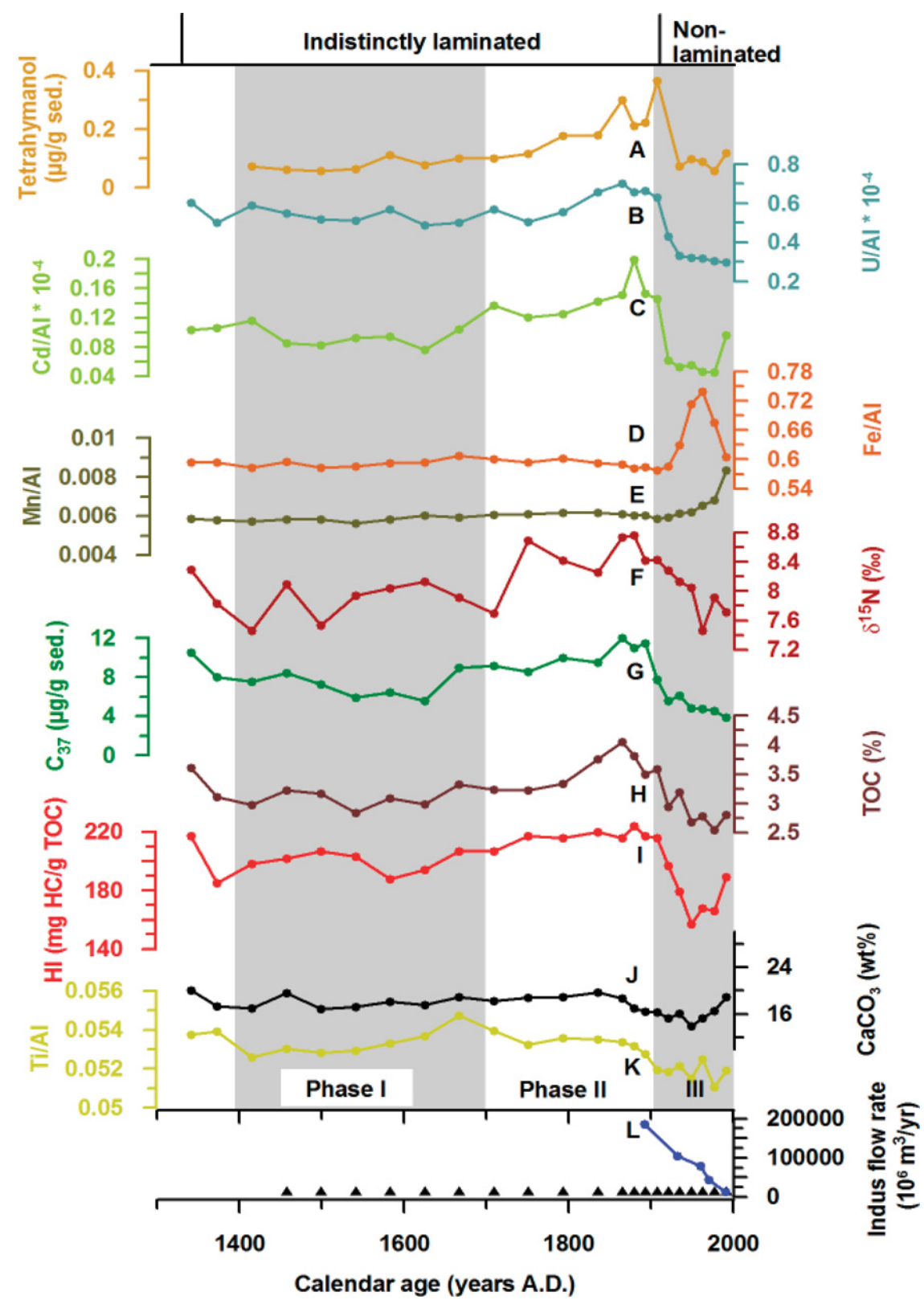

Figure 2. Inorganic and organic geochemical data from core SO130-288MC. A: Tetrahymanol provides biomarker for ciliates living at suboxic to anoxic interfaces. B-E: Redox state of sediments. B: Uranium. C: Cadmium. D: Iron. E: Manganese (normalized to $\mathrm{Al}$ ). $\mathrm{F}: \delta^{15} \mathrm{~N}$ is characteristic for oxygen-minimum zone conditions during deposition of sediments. G: $\mathrm{C}_{37}$ alkenones are biomarkers for haptophyte algae and provide, like total organic carbon (TOC), a proxy for primary productivity in the ocean. $\mathrm{H}$ : TOC. I: $\mathrm{HI}$ (hydrogen index) is measure of preservation state of organic matter. $\mathrm{J}$ : $\mathrm{CaCO}_{3}(\mathrm{wt} \%)$ mirrors increase in uppermost interval of sediments. K: Titanium (normalized to Al) reflects changes in discharge rates of terrigenous fraction. L: Indus River discharge rates are documented for past $120 \mathrm{yr}$ (Milliman et al., 1984; Inam et al., 2007). Black triangles denote sampling locations for ${ }^{210} \mathrm{~Pb}$ analyses. tary sequence. The distributions of $\mathrm{Mn}$ and $\mathrm{Fe}$ reflect the diagenetic status rather than changes in the supply of both elements and coincide with the interval where the sediments are not laminated. Both are indicative of suboxic conditions. $\mathrm{U}$ and $\mathrm{Cd}$, elements that are fixed in anoxic parts of sediment, typically below the iron redox boundary, are not enriched until below a depth of $\sim 5 \mathrm{~cm}$ (Fig. 2). This depth succession of the enrichments of redox-sensitive elements indicates non-steady-state diagenesis, as described by Reitz et al. (2004). A shift to lower total organic carbon (TOC) input is likely to have induced this non-steady-state diagenetic period.

The concentration of the biomarker tetrahymanol parallels the U/Al profile (Fig. 2). Tetrahymanol is synthesized by marine ciliates (Sinninghe Damsté et al., 1995). The diet of ciliates is sulfide-oxidizing bacteria living at the transition of suboxic to anoxic environments (Thiel et al., 1997). Therefore, the relatively low concentration near the sediment surface further indicates an increase in oxygen contents in the bottom water, in concert with the distribution of the redox-sensitive trace metals.

Sediment $\delta^{15} \mathrm{~N}$ values are within a range of $7.5 \%$ o $-8.8 \%$ o. The lowest values occur in the near-surface sediments, which are also seen in nearby locations within OMZ sediments (Fig. 2; Cowie et al., 2009). TOC varies between $2.5 \%$ and $4.1 \%$. The highest TOC contents were encountered in the interval with highest $\delta^{15} \mathrm{~N}$ values. Productivity-indicating biomarkers like alkenones (Fig. 2; Volkman et al., 1995) and diols (not shown; Sinninghe Damsté et al., 2003) suggest, in concert with TOC, a phase of enhanced productivity lasting more than $200 \mathrm{yr}$ and indicate a distinct decline of TOC burial during the past century. The hydrogen index (HI) is lowest in this uppermost interval (Fig. 2). A microscopic study indicates that the contribution of hydrogen-poor terrestrial organic matter $(\mathrm{OM})$ in all samples is low $(<2 \%)$ and rather constant (Table DR1). This excludes the possibility that variable $\mathrm{HI}$ values are caused by variable input of OM from different sources; instead, $\mathrm{HI}$ values express the preservation state of OM (Lückge et al., 2002).

\section{DISCUSSION}

Paleoproductivity in the Arabian Sea is usually discussed in the context of monsoon circulation, but the role of the Indus River, responsible for the enormous supply of water, sediments, and nutrients to the sea, is overlooked. Today, the Indus River is one of the most intensively used rivers worldwide. Since the end of the $19^{\text {th }}$ century, irrigation facilities and dams have changed the water budget and sediment load dramatically. The freshwater supply declined by more than $70 \%$ (to 90\%) during this period (Fig. 2; Milliman et al., 1984; Inam et al., 2007). As a 
consequence, the Indus Canyon, which has fed the huge Indus fan with rather coarse-grained material, is becoming inactive. Sedimentation is restricted to fine-grained material that is delivered primarily to the continental slope (Prins and Postma, 2000; Clift et al., 2008).

During these past decades, the Ti/Al ratio, which is not affected by postdepositional alteration, also declines significantly in the core (Fig. 2). Sediment type studies in the Arabian Sea (von Rad et al., 1999; Prins and Postma, 2000) demonstrated that $\mathrm{Al}$ is an indicator of clay detritus derived from the continent. Lückge et al. (2001) proposed that variations in the $\mathrm{Ti} / \mathrm{Al}$ ratio in sediments off the Makran coast are mainly the result of changes in fluvial discharge rates. The shape of the Ti/Al profile and its temporal correlation with discharge rates during the past decades suggest that variations in the composition of sediments are directly linked to changes in the drainage pattern of the Indus River. Because of the vicinity of the core to the Indus mouth, river runoff transporting suspended material is the most likely source for sediments (Clift et al., 2008). Eolian transport, which is the major terrigenous sediment source in the distal part of the Arabian Sea (Sirocko et al., 1993), is of minor importance. Metivier and Gaudemer (1999) and Clift et al. (2008) demonstrated that sediment buffering in river terraces and floodplains reacts on much larger time scales $\left(10^{5}-10^{6} \mathrm{yr}\right)$. Changes in natural sediment buffering are therefore likely of minor importance. Grain-size analyses do not show significant grain-size variations (Table DR2), and changes in eolian versus fluvial input can be neglected (Prins and Postma, 2000). We can assume that variations in Ti/Al since ca. A.D. 1900 are most likely caused by damming and irrigation facilities. These processes had the effect of reducing the water and sediment transport, and thus changed the geochemical signature of transported material.

The radiometric dating provides evidence that sedimentation rates were constant within $20 \%$ uncertainty. The sedimentation rates are probably kept constant due to increasing $\mathrm{CaCO}_{3}$ contents (from $13 \%$ to $19 \%$ ) in the uppermost interval (Fig. 2). It seems to be likely that lower organic carbon productivity has resulted in less corrosive bottom water, leading to a better preservation and accumulation of $\mathrm{CaCO}_{3}$. Changes due to enhanced erosion because of intensified land use seem to be unlikely since in this case we should expect increasing sedimentation rates.

The TOC and productivity-indicating biomarker records (Fig. 2) suggest that marine productivity declined during the phase of diminished discharge. Milliman et al. (1984) postulated that the drastic decrease of river discharge may have consequences for the nutrient supply and thus productivity in the Arabian Sea. Significant decreasing summer and/or winter monsoon activities that may lower the marine productivity and may explain lower TOC concentrations are not known from this period. Anderson et al. (2002) found that summer monsoon wind strength increased during the past 400 yr. Accordingly, Goes et al. (2005) reported for recent years that decreasing Eurasian snow cover is favorable to stronger southwestern monsoon, and thus increasing productivity. Studies on corals present evidence for rather constant northeastern monsoon activity during the past decades (Tudhope et al., 1996). Dahl and Oppo (2006) noted that sea surface temperatures (SSTs) are sensitive to the strength of the monsoon winds. Alkenone-based SSTs show more or less constant values, including the suggested period of diminished river discharge (Fig. DR2), and further support our conclusion that variations of marine hydrographical processes had minor influences on productivity changes. Instead, it is more likely that decreasing nutrient supply due to decreasing discharge from the Indus River has led to a regional decline in productivity. This may also explain the pattern that can be seen in the distribution of the redox-sensitive elements (Fig. 2). Because the $\log { }^{210} \mathrm{~Pb}$ activity decreases linear with depth (Fig. DR1), we can exclude that sedimentation was disturbed by any postsedimentary processes. Instead, the geochemical patterns most likely document synsedimentary changes due to declining marine productivity. Low $\mathrm{HI}$ values in the sediments of the past $\sim 100 \mathrm{yr}$ argue for more intense degradation of OM. Decreasing marine productivity is probably accompanied by a slight weakening of the OMZ and/or an intensification of the decay of OM. Sedimentary $\delta^{15} \mathrm{~N}$ values vary in concert with productivity, as expressed by TOC and alkenones. The range in $\delta^{15} \mathrm{~N}$ is typical of marine high productivity areas affected by water-column denitrification (Cowie et al., 2009). The decline in $\delta^{15} \mathrm{~N}$ over the past century suggests that the reduction in river flow and the concurrent reduction in coastal productivity reduced the local intensity of water-column denitrification, through a contraction in the OMZ volume and/or a decrease in the volumenormalized denitrification rate through reduced organic matter supply (Suthhof et al., 2001; Reichart et al., 1998).

\section{PALEOCEANOGRAPHIC IMPLICATIONS}

The geochemical records show that significant environmental changes have occurred during the past centuries. Our data suggest that the sedimentary history of core SO130-288MC can be subdivided into three phases (Fig. 2). Ice core data from the Tibetan Plateau and tree ring records from Karakoram (Treydte et al.,
2006) describe a dry and cold period, probably with relaxed monsoons, between A.D. 1400 and ca. 1700 (Mann et al., 2009). Gupta et al. (2003) demonstrated that, during that time, summer monsoon intensity and thus upwelling were less intense in the western Arabian Sea. This cool period, which correlates with colder temperatures in the North Atlantic (Gupta et al., 2003), was probably accompanied by low Indus discharge rates, as indicated by low Ti/Al ratios. During this period, which was characterized by lower snow-line elevations in the Karakoram and Himalaya mountains (Kuhle, 1999), runoff was lower because of reduced precipitation and increased retention as snow. During this time coastal productivity was relatively low, as indicated by TOC and biomarkers. During a second phase, from A.D. 1700 to ca. 1900, the southwest monsoon was intensified (Chauhan et al., 2010), and the freshwater input from the Indus River was high. During this phase, marine productivity was high. During the third phase, from ca. A.D. 1900 to 1998, marine productivity declined, although monsoon strength remained favorable for enhanced production and/or preservation of marine organic matter (Gupta et al., 2003; Anderson et al., 2002).

\section{CONCLUSIONS}

Paleoproductivity proxies in the northeastern Arabian Sea are usually discussed in the context of monsoon circulation, but the impact of the Indus River on coastal productivity, redox conditions, and sedimentation may be substantial. Our study suggests that the human-driven hydrological changes on land over the past century may have had a significant effect on offshore productivity and TOC burial. Anthropogenic redistribution of the Indus flow appears to have altered the chemical and physical conditions of the coastal sedimentary environment. Our results provide further motivation for investigating the impacts of human activities on the transport rates of water, sediment, and dissolved constituents to the coastal areas of oceans; specifically, monitoring the sedimentation offshore the Indus River might improve our understanding of the human perturbation of this drainage system. The devastating floods that followed heavy monsoon rains in the summer of 2010 in Pakistan might be used as a test case for the implications of changing Indus River discharge on the marine offshore ecosystem, helping to improve flood management strategies. Our results also give a sense of the scale of locally driven human changes in this coastal system, relative to those driven by past climate change.

\section{ACKNOWLEDGMENTS}

We thank P. Meyers and two anonymous referees for their constructive comments. We are grateful to the Bundesministerium für Bildung und Forschung for funding (no. 03G0130A). 


\section{REFERENCES CITED}

Anderson, D.M., Overpeck, J.T., and Gupta, A.K., 2002, Increase in the Asian southwest monsoon during the past four centuries: Science, v. 297, p. 596-599, doi:10.1126/science.1072881.

Chauhan, O.S., Dayal, A.M., Basavaiah, N., and Kader, U.S.A., 2010, Indian summer monsoon and winter hydrographic variations over past millennia resolved by clay sedimentation: Geochemistry Geophysics Geosystems, v. 11, Q09009, doi:10.1029/2010GC003067.

Clift, P.D., Giosan, L., Blusztajn, J., Campbell, I.H., Allen, C., Tabrez, A.R., Danish, M., Rabbani, M.M., Alizai, A., Carter, A., and Lückge, A., 2008, Holocene erosion of the Lesser Himalaya triggered by intensified summer monsoon: Geology, v. 36, p. 79-82, doi:10.1130/G24315A.1.

Cowie, G.L., Calvert, S.E., Pedersen, T.F., Schulz, H., and von Rad, U., 1999, Organic content and preservational controls in surficial shelf and slope sediments from the Arabian Sea (Pakistan margin): Marine Geology, v. 161, p. 23-38, doi:10.1016/S0025-3227(99)00053-5.

Cowie, G.L., Mowbray, S., Lewis, M., Matheson, H. and McKenzie, R., 2009, Carbon and nitrogen elemental and stable isotopic compositions of surficial sediments from the Pakistan margin of the Arabian Sea: Deep-Sea Research, v. 56, p. 271-282, doi:10.1016/j.dsr2.2008.05.031.

Dahl, K.A., and Oppo, D., 2006, Sea surface temperature pattern reconstructions in the Arabian Sea: Paleoceanography, v. 21, PA1014, doi:10.1029/2005PA001162.

Goes, J.I., Thoppil, P.G., do Gomes, R.H., and Fasullo, J.T., 2005, Warming of the Eurasian landmass is making the Arabian Sea more productive: Science, v. 308, p. 545-547, doi:10.1126/ science. 1106610 .

Gupta, A.K., Anderson, D.M., and Overpeck, J.T., 2003, Abrupt changes in the Asian southwest monsoon during the Holocene and their links to the North Atlantic Ocean: Nature, v. 421, p. 354-357, doi:10.1038/nature01340.

Haake, B., Ittekkot, V., Ramaswamy, V., Nair, R.R., and Curry, W.B., 1993, Seasonality and interannual variability of particle fluxes to the deep Arabian Sea: Deep-Sea Research, v. 40, p. 1323 1344, doi:10.1016/0967-0637(93)90114-I.

Inam, A., Clift, P.D., Giosan, L., Tabrez, A.R., Tahir, M., Rabbani, M.M., and Danish, M., 2007, The geographic, geological and oceanographic setting of the Indus River, in Gupta, A., ed., Large rivers: Geomorphology and management: New York, John Wiley \& Sons, Ltd., p. 333-345.

Ittekkot, V., and Arain, R., 1986, Nature of particulate organic matter in the river Indus, Pakistan: Geochimica et Cosmochimica Acta, v. 50, p. 1643 1653, doi:10.1016/0016-7037(86)90127-4.

Kale, V.S., 2007, Fluvio-sedimentary response of the monsoon-fed Indian rivers to late PleistoceneHolocene changes in monsoon strength: Reconstruction based on existing ${ }^{14} \mathrm{C}$ dates: Quaternary Science Reviews, v. 26, p. 1610-1620, doi:10.1016/j.quascirev.2007.03.012.

Karim, A., and Veizer, J., 2002, Water balance of the Indus River Basin and moisture source in the Karakoram and western Himalayas: Implications from hydrogen and oxygen isotopes in river water: Journal of Geophysical Research, v. 107, no. D18, 4362, doi:10.1029/2000JD000253.

Kudrass, H.R., Hofmann, A., Doose, H., Emeis, K.-C., and Erlenkeuser, H., 2001, Modulation and amplification of climatic changes in the Northern Hemisphere by the Indian summer monsoon during the past $80 \mathrm{k} . \mathrm{y}$ : Geology, v. 29, p. $63-$ 66, doi:10.1130/0091-7613(2001)029<0063: MAAOCC $>2.0 . \mathrm{CO} ; 2$

Kuhle, M., 1999, Reconstruction of an approximately complete Quaternary Tibetan inland glaciation between the Mt. Everest and Cho Oyu Massifs and the Aksai Chin. A new glaciogeomorphological SE-NW diagonal profile through Tibet and its consequences for the glacial isostasy and Ice Age cycle: GeoJournal, v. 47, p. 3-276, doi:10.1023/A:1007039510460.

Lückge, A., Doose-Rolinski, H., Khan, A.A., Schulz, H., and von Rad, U., 2001, Monsoonal variability in the northeastern Arabian Sea during the past 5000 years: Geochemical evidence from laminated sediments: Palaeogeography, Palaeoclimatology, Palaeoecology, v. 167, p. 273-286, doi:10.1016/S0031-0182(00)00241-8.

Lückge, A., Horsfield, B., Littke, R., and Scheeder, G., 2002, Organic matter preservation and sulfur uptake in sediments from the continental margin off Pakistan: Organic Geochemistry, v. 33, p. 477488, doi:10.1016/S0146-6380(01)00171-1.

Mann, M.E., Zhang, Z., Rutherford, S., Bradley, R.S., Hughes, M.K., Shindell, D., Ammann, C., Faluvegi, G., and Ni, F., 2009, Global signatures and dynamical origins of the Little Ice Age and medieval climate anomaly: Science, v. 326, p. 1256-1260, doi:10.1126/science.1177303.

Metivier, F., and Gaudemer, Y., 1999, Stability of output fluxes of large rivers in South and East Asia during the last 2 million years; implications of floodplain processes: Basin Research, v. 11, p. 293303, doi:10.1046/j.1365-2117.1999.00101.x.

Milliman, J.D., Quraishee, G.S., and Beg, M.A.A., 1984, Sediment discharge from the Indus River to the Ocean: Past, present, future, in Haq, B., and Milliman, J.D., eds., Marine geology and oceanography of Arabian Sea and coastal Pakistan: New York, van Nostrand Reinhold, p. 65-70.

Prell, W.L., and Kutzbach, J.E., 1992, Sensitivity of the Indian monsoon to forcing parameters and implications for its evolution: Nature, v. 360 , p. 647-652, doi:10.1038/360647a0.

Prins, M.A., and Postma, G., 2000, Effects of climate, sea level, and tectonics unraveled for last deglaciation turbidite records of the Arabian Sea: Geology, v. 28, p. 375-378, doi:10.1130/0091-7613 (2000) $28<375$ :EOCSLA $>2.0$. CO;2.

Reichart, G.J., Lourens, L.J., and Zachariasse, J.W., 1998, Temporal variability in the northern Arabian Sea Oxygen Minimum Zone (OMZ) during the last 225,000 years: Paleoceanography, v. 13, p. 607-621, doi:10.1029/98PA02203.

Reitz, A., Hensen, C., Kasten, S., Funk, J., and de Lange, G., 2004, A combined geochemical and rock-magnetic investigation of a redox horizon at the last glacial/interglacial transition: Physics and Chemistry of the Earth, v. 29, p. 921-931, doi:10.1016/j.pce.2004.03.013.

Sinninghe Damsté, J.S., Kenig, F., Koopmans, M.P., Köster, J., Schouten, S., Hayes, J.M., and de
Leeuw, J.W., 1995, Evidence for gammacerane as an indicator of water column stratification: Geochimica et Cosmochimica Acta, v. 59, p. 18951900, doi:10.1016/0016-7037(95)00073-9.

Sinninghe Damsté, J.S., Rampen, S., Rijpstra, I.W.C., Abbas, B., Muyzer, G., and Schouten, S., 2003, A diatomaceous origin for long-chain diols and mid-chain hydroxy methyl alkanoates widely occurring in Quaternary marine sediments: Indicators for high-nutrient conditions: Geochimica et Cosmochimica Acta, v. 67, p. 1339-1348, doi:10.1016/S0016-7037(02)01225-5.

Sirocko, F., Sarnthein, M., Erlenkeuser, H., Lange, H., Arnold, M., and Duplessy, J.C., 1993, Century-scale events in monsoonal climate over the past 24,000 years: Nature, v. 364, p. 322-324, doi: $10.1038 / 364322 \mathrm{a} 0$.

Suthhof, A., Ittekkot, V., and Gaye-Haake, B., 2001, Millennial-scale oscillation of denitrification intensity in the Arabian Sea during the late Quaternary and its potential influence on atmospheric $\mathrm{N}_{2} \mathrm{O}$ and global climate: Global Biogeochemical Cycles, v. 15, p. 637-649, doi:10.1029 /2000GB001337.

Syvitski, J.P.M., Vörösmarty, C.J., Kettner, A.J., and Green, P., 2005, Impact of humans on the flux of terrestrial sediment to the global coastal ocean: Science, v. 308, p. 376-380, doi:10.1126/science .1109454.

Thiel, V., Jenisch, A., Landmann, G., Reimer, A., and Michaelis, W., 1997, Unusual distribution of long-chain alkenones and tetrahymanol from the highly alkaline Lake Van, Turkey: Geochimica et Cosmochimica Acta, v. 61, p. 2053-2064, doi:10.1016/S0016-7037(97)00038-0.

Treydte, K.S., Schleser, G.H., Helle, G., Frank, D.C., Winiger, M., Haug, G.H., and Esper, J., 2006, The twentieth century was the wettest period in northern Pakistan over the past millenium: Nature, v. 440, p. 1179-1182, doi:10.1038/nature04743.

Tudhope, A., Lea, D.W., Shimmield, G.B., Chilcott, C.P., and Head, S., 1996, Monsoon climate and Arabian Sea coastal upwelling recorded in massive corals from southern Oman: Palaios, v. 11, p. 347-362.

Volkman, J.K., Barrett, S.M., Blackburn, S.I., and Sikes, E.L., 1995, Alkenones in Geophyrocapsa oceanica: Implications for studies of paleoclimate: Geochimica et Cosmochimica Acta, v. 59 p. 513-520, doi:10.1016/0016-7037(95)00325-T.

van der Weijden, C.H., Reichart, G.J., and Visser, H.J., 1999, Enhanced preservation of organic matter in sediments underlying the oxygen minimum zone in the northeastern Arabian Sea: Deep-Sea Research, v. 46, p. 807-830, doi:10.1016/S0967 $-0637(98) 00093-4$

von Rad, U., Schulz, H., Riech, V., den Dulk, M., Berner, U., and Sirocko, F., 1999, Multiple monsooncontrolled breakdown of oxygen-minimum conditions during the past 30,000 years documented in laminated sediments off Pakistan: Palaeogeography, Palaeoclimatology, Palaeoecology, v. 152, p. 129-161, doi:10.1016/S0031-0182(99)00042-5.

Manuscript received 30 June 2011

Revised manuscript received 1 December 2011

Manuscript accepted 1 December 2011

Printed in USA 